\title{
Does the spin-off policy can accelerate the deposit funds in the Indonesian Islamic banking industry?
}

\author{
M Nur Rianto Al Arif \\ Universitas Islam Negeri Syarif Hidayatullah, Indonesia
}

\section{Keywords}

spin-off; deposit fund; panel regression; Islamic banks

\begin{abstract}
The purpose of this paper is to analyze the impact of spin-off policy that based on Islamic Banking Act No. 21/2008 to the deposit fund growth of Islamic banking industry in Indonesia. This research used panel regression with fixed effect. The variable used in this paper is spin-off variable that used as a dummy variable, and also included the internal factor of industry such as deposit margin, and efficiency ratio (measured by BOPO). Besides the internal element, this research also added the external factor such as economic growth rate, and net interest margin from conventional banking. The result showed that the dummy spin-off variable, operational efficiency ratio (BOPO) and growth rate had an impact on the deposit funds in four Islamic banks. The implication of this result is spin-off policy had a good effect on the growth of deposit funds in Indonesian Islamic banking industry. Spin-off decision is one of the business strategies from Islamic banks and not the goal of Islamic banking industry.
\end{abstract}

Corresponding author: M Nur Rianto Al Arif

Email address for corresponding author: nur.rianto@uinjkt.ac.id

First submission received: $1^{\text {st }}$ November 2017

Revised submission received: $2^{\text {th }}$ January 2018

Accepted: $13^{\text {th }}$ March 2018

\section{Introduction}

This study found that there is a difference in deposit funds at the spin-off's banks between before and after the spin-off. This research is consistent with Al Arif (2014) that also found that there is a difference in deposit funds at Islamic banking industry between before and after the spin-off. The differences between these studies with previous research are on the object of study. This study uses the object on spin-offs' banks, whereas previous studies focused on data at the industry level. But, this research is different with Al Arif et al. (2017) that found that there is no impact of spin-off policy on the deposit funds.

Islamic economic development in Indonesia characterized by the presence of Bank of Muamalat Indonesia as the first Islamic bank in Indonesia in 1992 and then followed by the presence of various Islamic financial institutions. Market share of Islamic banking in Indonesia today is still relatively small, only $5 \%$ of total bank assets national. The number of Islamic bank customer today just about 3 million people, though the number of Muslims to be potential consumers Islamic banks more than 100 million people. Thus, the majority of Muslims have not associated with Islamic banks. Table 1 shows the growth of Islamic banking industry in Indonesia, until the end of 2016, there are 13 Islamic full-pledge banks, 21 Islamic business units, and 166 Islamic rural banks. From 13 Islamic full-pledge banks, five banks are the result of spin-off decision, either by acquisition and merger or pure spin-off.

Table 1. Islamic banking network

\begin{tabular}{lllllllllll}
\hline & 2007 & 2008 & 2009 & 2010 & 2011 & 2012 & 2013 & 2014 & 2015 & 2016 \\
\cline { 2 - 9 } Islamic banking & & & & & & & & & & \\
Islamic commercial bank & 3 & 5 & 6 & 11 & 11 & 11 & 11 & 12 & 12 & 13 \\
Islamic business unit & 26 & 27 & 25 & 23 & 23 & 24 & 23 & 22 & 22 & 21 \\
Islamic rural bank & 114 & 131 & 138 & 150 & 154 & 158 & 163 & 163 & 163 & 166 \\
\hline
\end{tabular}

Source: Islamic banking statistics, Bank of Indonesia

In 2008, has passed Act No. 21 of 2008 concerning Islamic Banking. This Act provides the legal basis of Indonesian Islamic banking industry, and also to encourage the development of Islamic banking 
industry. One of the crucial issues in this regulation related to the obligation of Islamic business units to separate (spin-off) if the asset Islamic business unit reached $50 \%$ of the parent bank's assets or 15 years after the Act No. 21 of 2008 applied.

There are several reasons about the proposed of spin-off policy, such as: first, to accelerate the growth of the Islamic banking industry; second, to increase the performance of Islamic banks; third, it will increase the independence of Islamic banks; fourth, the Sharia compliance. After the enactment of Act No. 21 of 2008, there appeared a new trend establishment of Islamic banks. Implementation can do through three approaches, namely: First, conventional commercial banks already had Islamic banking unit acquires a relatively small bank then convert it into full Islamic banking and release as well as incorporating Islamic banking unit with the newly converted bank. Second, conventional commercial banks do not have Islamic banking unit, acquired a relatively small bank and turn it into an Islamic fullfledge bank. Third, conventional bank separation (spin-off) and used as a separate Islamic Banks

Table 2 shows the development of deposit funds, financing, and asset in Indonesian Islamic banking industry. The data shows that there are the increasing of deposit funds, financing, and asset from the Islamic banking industry. But, if we see the growth, the data shows that since 2012 there is declining growth in Islamic banking growth either in deposit funds, financing, and asset. In 2014, the growth was below $8 \%$; the data implies that the spin-off policy that imposed by the regulator still don't have an impact on Indonesian Islamic banking industry growth.

Tabel 2. The Development of Deposit, Financing, and Asset

\begin{tabular}{lllllllllll}
\hline & \multicolumn{10}{c}{ (on billion rupiahs) } \\
\hline Deposit fund & 2007 & 2008 & 2009 & 2010 & 2011 & 2012 & 2013 & 2014 & 2015 & 2016 \\
Growth (\%) & 35,50 & 36,852 & 52,271 & 76,036 & 115,415 & 147,512 & 174,018 & 186,608 & 231,175 & 279,335 \\
Financing & 27.944 & 38,194 & 41.84 & 45.46 & 51.80 & 27.81 & 17.97 & 7.23 & 23.88 & 20.83 \\
Growth (\%) & 36,69 & 36.68 & 22.76 & 45,181 & 102,655 & 147,505 & 179,284 & 187,886 & 212,996 & 248,007 \\
Asset & 36.537 & 49,555 & 66,090 & 97,519 & 145,467 & 195,018 & 229,557 & 244,197 & 296,262 & 356,504 \\
Growth (\%) & 36,73 & 35.63 & 33.37 & 47.55 & 49.17 & 34.06 & 17.71 & 6.38 & 21.32 & 20.33 \\
\hline
\end{tabular}

Source: Islamic Banking Statistics, Bank of Indonesia

Novarini (2009), Pramuka (2011), and Endri (2011) found that the more significant part of Islamic business unit is not efficient regarding profits. The level of efficiency of Islamic full pledge banks is higher than Islamic business units. The spin-off will undoubtedly lead to potential new problems in the Islamic Business Unit, which will split. When the time becomes, Islamic business unit is inefficient how if it decides Islamic business unit convert into Islamic Banks should be able to carry out banking operations independently and is no longer dependent on the Conventional Commercial Bank became the parent. Al Arif (2015) shows that the spin-off policy has increased the operational inefficiency of Indonesian Islamic banking industry.

Based on the data, it appears that the spin-off policy still raises several problems. Therefore, this research seeks to examine the impact of spin-off policies on deposit funds in spin-offs' banks. The discussion on this article will consist of several sections. In the first part will attempt to explain the gaps contained in this study. Then in the second part explains the literature review of spin-offs in the Islamic banking industry. The third section describes the analytical techniques used in this study. In the fourth chapter will explain the empirical findings obtained in this study.

\section{Literature Review}

There had been some researchers associated with the spin-off in Islamic banks. The spin-off of Islamic banks only first practiced in Indonesia. Therefore, theories or models of the spin-off will do with the model of spin-offs are applied to industry in general. Al Arif et al. (2017) and Haribowo (2017) stated that the spin-off policy should evaluate.

Nasuha (2012) conducted a study about the performance difference on Islamic banking unit that decided to the spin-off, such as BNI Sharia, BRI Sharia, BJB Sharia, BSB and Victoria Sharia. The result showed that only asset, financing and deposit funds that indicated a difference between before and after spin-off policies on that five banks. Otherwise for other variables such as CAR, FDR, ROA, and ROE showed that there was no difference between pre and post spin-off. Kiswono (2012) conducted a study of strategy

www.jbrmr.com A Journal of the Academy of Business and Retail Management (ABRM) 
formulation to Islamic business unit's spin-off. This research shows that only several spin-off roadmaps that reasonable to be realized, such as Bank of Permata, Bank of BTN, Bank of CIMB Niaga, and Bank of Danamon. Several strategies can do by the Islamic business unit, such as a pure spin-off, merger, acquisition, and conversion.

Al Arif (2014) researches the impact of spin-off policy on deposit fund in Islamic banking industry using the data on Islamic banking industry statistics. The result shows that all the independent variables such as dummy variable of the spin-off, one-month time deposit margin, operational efficiency ratio (BOPO), and profitability ratio (ROA) had an impact on the growth of deposit funds on Islamic banking industry. Siswantoro (2014) analyze the performance and the strategy of Islamic bank after the spinoff decision, most Islamic banks that have converted in the full-pledge scheme could optimize some source of funding such as capital injection and increasing temporary investment deposit. Ramdani (2015) and Hamid (2015) found that there is a difference in profit between before and after spin-off policy. Ramdani (2015) focused on the study at Bank of BNI Sharia and Hamid (2015) targeted at Indonesian Islamic banking industry.

Al Arif (2015) analyzes the relationship between spin-off policies on the financing growth of Indonesian Islamic banking industry. This research using the panel regression with fixed effect model. The variables that used in this paper are dummy variable spin-off, deposit funds, efficiency ratio, inflation rate, economic growth rate, and interest rate. The result showed that only deposit funds and the interest rate that has an impact on the financing growth in spin-off banks. This result implies that the spin-off policy that imposed by the regulator didn't affect financing Islamic banking financing growth.

According to Elfring and Foss (1997), there are two types of the spin-off, namely: first, regarding its parent company, in which the parent company for some reason is not able or not able to exploit the opportunities that come. The second type is related to organizational units as an individual, which the subsidiary is not the same as its parent company. Christo and Falk (2006) showed that the critical factor of the spin-off is the focused of the industry. From these results and we related to this research, we can state that the spinoff decision that had been done by several Islamic banking units can give a value for the parent's company and also for the shareholders. Because the parent's company can focus on his primary business, and the subsidiary company can concentrate to develop.

\section{Method}

This study uses regression analysis to panel data. The data used are quarterly data from 2005 to 2016, by including four Islamic banks spinoff (such as Bank of BNI Sharia, Bank of BRI Sharia, Bank of Bukopin Sharia, and Bank of BJB Sharia). The reason why only uses these four banks are: (1) these four banks are quite long enough as Islamic business unit, i.e., more than five years; (2) these four banks had already done the spinoff, i.e., more than five years; (3) the availability of data. This study does not include all Islamic banks because of the focus of this research only on spin-offs' banks.

Statistical data comes from Bank Indonesia Islamic banking and Islamic commercial bank's financial statements results of the spin-off, which is the object of research. To examine the effect of spin-off policy on deposit fund is using panel regression. The mathematical equation proposed in this research is: Ln_Dep $_{i t}=\alpha+\beta_{1} D_{i t}+\beta_{2}$ Margin $_{i t}+\beta_{3}$ BOPO $_{i t}+\beta_{4}$ Interest $_{t}+\beta_{5}$ Growth $_{t}+\varepsilon_{i t}$ where:

$L n_{-} \operatorname{Dep}_{t}=\log$ natural of deposit funds;

$D_{\mathrm{t}}=$ Dummy variable for spin-off

Which is: 0 before spin-off, 1 after spin-off

Margin $=$ three-month deposit's margin

$\mathrm{BOPO}=$ operational efficiency ratio

Interest $=$ net interest margin from conventional banks

Growth $=$ economic growth of Indonesia

To estimate the parameter of the model using panel data regression. Several techniques can be used, such as First, ordinary least square. Second, fixed effect model. Third, random effect model. On this research is using panel regression with fixed effect model, because we assume that the intercept is not constant. There are several steps in this research, such as: first, run the estimation using fixed-effect 
model. Second, do the Chow-test to choose between pooled ordinary least square or fixed effect model. Third, do the Hausman-test to select between fixed effect model and random effect model.

\section{Result}

The first step in this research we estimate using fixed-effect model. After that using the Chow-test we can see that we reject the null hypothesis which stated that intercept is constant in $i$ and $t$, so the best model is fixed effect model. We can see the Chow-test result in Table 3. The next step we estimate the equation with random effect model. After that using the using the Hausman-test, we can see that we reject the null hypothesis which stated the random effect model is consistent, so the best model that chose on this research is fixed effect model. We can see the Hausman-test result in Table 4. The estimation result from panel regression with fixed effect shown that the variables that affect the deposit fund on Islamic banks result from spin-off is dummy variable of spin-off, operational efficiency ratio (BOPO), interest rate, and growth rate variables. Dummy variable spin-off has a positive influence on the growth of deposit funds in four Islamic banks are becoming observation. This result suggests that the decision to separate Islamic banking unit into Islamic commercial bank can improve deposit funds in Islamic banks.

The results that obtained from this paper is consistent with that research that done by Al Arif (2014). In previous studies trying to look at the impact of spin-off policy towards the Islamic banking industry in general by using Islamic banking data from Islamic Banking Statistics from Bank Indonesia. In a previous study using the independent variable in the form of a dummy variable separation, the level of financing problems (NPF), a margin deposit one month, the value of the efficiency ratio (ROA), and the level of profitability (ROA). The results showed that all independent variables have a significant impact on deposit funds in the Islamic banking industry in Indonesia.

Table 3. Chow-Test Result

\begin{tabular}{|c|c|c|c|c|}
\hline \multicolumn{5}{|c|}{$\begin{array}{l}\text { Redundant Fixed Effects Tests } \\
\text { Equation: HASIL_REV_FE } \\
\text { Test cross-section fixed effects }\end{array}$} \\
\hline Effects Test & & Statistic & d.f. & Prob. \\
\hline Cross-section F & & 53.045298 & $(3,146)$ & 0.0000 \\
\hline $\begin{array}{l}\text { Cross-section fixed e } \\
\text { Dependent Variable: } \\
\text { Method: Panel EGLS } \\
\text { Total panel (balanced } \\
\text { Use pre-specified GL } \\
\text { White cross-section s }\end{array}$ & $\begin{array}{l}\text { quation: } \\
\text { tion weights) } \\
\text { ions: } 192 \\
\text { rors \& covari }\end{array}$ & nce (d.f. cor & ted) & \\
\hline Variable & Coefficient & Std. Error & t-Statistic & Prob. \\
\hline $\mathrm{C}$ & 16602961 & 1556168. & 10.66913 & 0.0000 \\
\hline D_SPINOFF & 2367796. & 446909.4 & 5.298157 & 0.0000 \\
\hline MARJIN & -135472.4 & 196442.4 & -0.689629 & 0.4915 \\
\hline BOPO & -7790.772 & 7195.877 & -1.082672 & 0.2807 \\
\hline INTEREST & -2810861. & 278523.2 & -10.09202 & 0.0000 \\
\hline \multirow[t]{2}{*}{ GROWTH } & 353849.1 & 163512.0 & 2.164056 & 0.0321 \\
\hline & \multicolumn{4}{|c|}{ Weighted Statistics } \\
\hline R-squared & 0.417427 & \multicolumn{2}{|c|}{ Mean dependent var } & 3292868. \\
\hline Adjusted R-squared & 0.393968 & \multicolumn{2}{|c|}{ S.D. dependent var } & 3668132. \\
\hline S.E. of regression & 3009774. & \multicolumn{2}{|c|}{ Sum squared resid } & $1.35 \mathrm{E}+15$ \\
\hline F-statistic & 17.79364 & \multicolumn{2}{|c|}{ Durbin-Watson stat } & 0.159298 \\
\hline Prob(F-statistic) & 0.000000 & & & \\
\hline \multicolumn{5}{|c|}{ Unweighted Statistics } \\
\hline R-squared & 0.394359 & Mean de & ndent var & 3146536. \\
\hline Sum squared resid & $1.43 \mathrm{E}+15$ & Durbin- & tson stat & 0.106752 \\
\hline
\end{tabular}

Similar results obtained by Nasuha (2012). Which conducts research related to differences in the performance of Islamic business unit who decided to split (Bank of BNI Sharia, Bank of BRI Sharia, Bank of BJB Sharia, Bank of Sharia Bukopin, and Bank of Victoria Sharia) one year before and one year after spin-off by using the Wilcoxon Match Pairs test. The result shows that there were the differences between before and after the spin-off on three variables, such as assets, financing, and deposit fund. 
The time-deposit margin shown that didn't have an impact on deposit funds in four spin-off banks. This result is different with Andriyanti and Wasilah (2010); Kasri (2010). Andriyanti and Wasilah (2010); Kasri (2010) found that the higher return of Islamic banks will increase the deposit funds growth. The difference established by the different data and method that used in this paper and previous research. The last study using the one-month time deposit margin, this article is using three-month time deposit margin. The preceding analysis using the ordinary least square regression, this paper used the panel regression with fixed effect model.

Operational efficiency ratio that measured by BOPO had a negative impact on deposit funds. This result shows that the more efficient indicated Islamic banks increasingly smaller values ROA ratio, the deposit funds will increase. It means that if the bank customer noticed that the more efficient Islamic banks, it would further enhance customer interest in putting their resources into Islamic banks. Variable net interest margin gives a negative influence on deposit fund; it shows that customers of Islamic banks in deciding to put their funds in Islamic banks still consider the interest rate offered by conventional banks. This result indicates that customers of Islamic banks are always rational customers, i.e., customers who always take into account Islamic banks give the rate of return compared to the conventional bank interest rate. This result is same as the research that done by Kasri (2010) and also by Andriyanti and Wasilah (2010), the interest rate also influences the growth of deposit funds. The higher of interest rate will decrease the deposit funds growth because there will be a customer's movement from Islamic banks into conventional banks.

Table 4. Hausman-test Result

\begin{tabular}{|c|c|c|c|c|}
\hline \multicolumn{5}{|c|}{$\begin{array}{l}\text { Correlated Random Effects - Hausman Test } \\
\text { Equation: Untitled } \\
\text { Test period random effects }\end{array}$} \\
\hline Test Summary & & Chi-Sq. Statistic & Chi-Sq. d.f. & Prob. \\
\hline Period random & & 37.382641 & 3 & 0.0000 \\
\hline Variable & Fixed & Random & Var(Diff.) & Prob. \\
\hline D_SPINOFF & -3468824.9851 & 3251553.6319 & 1446247364766.32 & 0.0000 \\
\hline MARJIN & 1317322.2108 & 176131.88685 & 44781681048.899 & 0.0000 \\
\hline $\mathrm{BOPO}$ & -3503.5630 & -14357.842722 & 39373426.3357 & 0.0837 \\
\hline $\begin{array}{l}\text { Period random effect } \\
\text { Dependent Variable: } \\
\text { Method: Panel Least } \\
\text { Total panel (balanced }\end{array}$ & $\begin{array}{l}\text { st equation: } \\
\text { K } \\
\text { ares } \\
\text { oservations: } 192\end{array}$ & & & \\
\hline Variable & Coefficient & Std. Error & t-Statistic & Prob. \\
\hline $\mathrm{C}$ & -4220648 & 2029439. & -2.079712 & 0.0398 \\
\hline D_SPINOFF & -3468825. & 1348153. & -2.573020 & 0.0114 \\
\hline MARJIN & 1317322. & 308267.7 & 4.273305 & 0.0000 \\
\hline $\mathrm{BOPO}$ & -3503.563 & 10740.78 & -0.326193 & 0.7449 \\
\hline INTEREST & NA & NA & NA & NA \\
\hline GROWTH & NA & NA & NA & NA \\
\hline \multicolumn{5}{|c|}{$\begin{array}{l}\text { Effects Specification } \\
\end{array}$} \\
\hline \multicolumn{5}{|c|}{ Period fixed (dummy variables) } \\
\hline R-squared & 0.625956 & \multicolumn{2}{|c|}{ Mean dependent var } & 3146536. \\
\hline Adjusted R-squared & 0.491432 & \multicolumn{2}{|c|}{ S.D. dependent var } & 3909315. \\
\hline S.E. of regression & 2787887. & \multicolumn{2}{|c|}{ Akaike info criterion } & 32.74427 \\
\hline Sum squared resid & $8.86 \mathrm{E}+14$ & \multicolumn{2}{|c|}{ Schwarz criterion } & 33.56539 \\
\hline Log likelihood & -2512.053 & \multicolumn{2}{|c|}{ Hannan-Quinn criter. } & 33.07777 \\
\hline F-statistic & 4.653104 & \multicolumn{2}{|c|}{ Durbin-Watson stat } & 0.187182 \\
\hline Prob(F-statistic) & 0.000000 & & & \\
\hline
\end{tabular}

The value of determination coefficient shows the amount of $\mathrm{R}^{2} 0.7212$ and the importance of adjusted $\mathrm{R}^{2} 0.7041$. This result indicates that fixed effect model can explain the model in about $70.41 \%$ and $29.59 \%$ explain by other variables outside the model. The values of $\mathrm{F}$ statistics show the significant result so that it can say that simultaneously all variables affect the dependent variable of deposit funds in Islamic banks. 


\section{Discussion}

The result from the result shows that the spin-off policy had an impact on deposit funds at four spin-off banks. Empirically the spin-off decision that made by four banks can increase the nominal of deposit funds, but if we see from Table 4, the spin-off decision didn't have an impact on deposit funds growth. This result implies that the increase of deposit funds caused by other factors besides the spin-off decision. The questioner result shows that although most of the respondents have known that the banks had already spin-off, the saving behavior of the respondent still not change. It means that the spin-off decision from the banks can't influence the saving behavior of the customers.

Table 5. Estimation With Fixed Effect Model

\begin{tabular}{|c|c|c|c|c|}
\hline $\begin{array}{l}\text { Dependent Variable: } \\
\text { Method: Panel EGLS } \\
\text { Sample: 2005Q1 } 2016 \\
\text { Periods included: } 48 \\
\text { Cross-sections incluc } \\
\text { Total panel (balance }\end{array}$ & $\begin{array}{l}4 \\
\text { bservations: }\end{array}$ & & & \\
\hline Variable & Coefficient & Std. Error & t-Statistic & Prob. \\
\hline $\mathrm{C}$ & 16845792 & 1541576. & 10.92764 & 0.0000 \\
\hline D_SPINOFF & 2700308. & 406353.9 & 6.645212 & 0.0000 \\
\hline MARGIN & -45596.41 & 142887.6 & -0.319107 & 0.7501 \\
\hline $\mathrm{BOPO}$ & -14006.42 & 5418.081 & -2.585126 & 0.0107 \\
\hline INTEREST & -2771424. & 277657.1 & -9.981466 & 0.0000 \\
\hline \multirow[t]{2}{*}{ GROWTH } & 333139.4 & 160470.5 & 2.076017 & 0.0396 \\
\hline & \multicolumn{4}{|c|}{ Effects Specification } \\
\hline \multicolumn{5}{|c|}{ Cross-section fixed (dummy variables) } \\
\hline & \multicolumn{4}{|c|}{ Weighted Statistics } \\
\hline R-squared & 0.721253 & Mean de & ent var & 3292868. \\
\hline Adjusted R-squared & 0.704070 & S.D. dep & t var & 3668132. \\
\hline S.E. of regression & 2103199. & Sum squ & esid & $6.46 \mathrm{E}+14$ \\
\hline F-statistic & 41.97474 & Durbin- & n stat & 0.337930 \\
\hline \multirow[t]{2}{*}{ Prob(F-statistic) } & 0.000000 & & & \\
\hline & \multicolumn{4}{|c|}{ Unweighted Statistics } \\
\hline R-squared & 0.654219 & Mean de & ent var & 3146536. \\
\hline Sum squared resid & $8.19 \mathrm{E}+14$ & Durbin- & n stat & 0.192211 \\
\hline
\end{tabular}

Table 6 shows that in the earlier period of spin-off decision the growth of deposit funds was increasing. This fact demonstrated by Bank of BRI Sharia and Bank of Bukopin Sharia that can achieve the deposit funds growth above 200 percent after the spin-off decision. Bank of BNI Sharia that has the stable growth after spin-off decision shows the different trend; the highest growth from Bank of BNI Sharia was before spin-off in 2008 that can achieve $69.07 \%$. Bank of BJB Sharia shows the declining growth after the spin-off decision. The highest growth is in 2009 that can reach $124.73 \%$, and this growth also stable in the spin-off's year (in 2010) that can achieve $124.07 \%$. From the data, we can see that the nominal deposit funds are always increasing, but the growth is declining.

Table 6. The Growth of Deposit Funds at Spin-offs' Banks (\%)

\begin{tabular}{llllllllllll}
\hline Bank & 2006 & 2007 & 2008 & 2009 & 2010 & 2011 & 2012 & 2013 & 2014 & 2015 & 2016 \\
\hline BNIS & 31.25 & 60.02 & 69.07 & 37.19 & $22.96^{*}$ & 31.66 & 32.91 & 27.93 & 36.24 & 18.94 & 25.34 \\
BRIS & 43.88 & 107.93 & $-24.26^{*}$ & 278.57 & 167.91 & 71.90 & 20.62 & 20.09 & 11.76 & 18.74 & 9.42 \\
BJBS & 91.01 & 26.92 & 43.64 & 124.73 & $124.07^{*}$ & 70.43 & 51.55 & 10.13 & 13.50 & -10.21 & 15.97 \\
BSB & 70.96 & 9.34 & $-54.59^{*}$ & 553.31 & 27.52 & 41.30 & 24.39 & 14.78 & 22.08 & 19.06 & 14.43 \\
\hline
\end{tabular}

*) Spin-off year

Source: data processing

This thing implies that the spin-off decision still can't accelerate the growth of four spin-off banks. From the questioner result, show that there are a lot of things that become the reason why customer choose the Islamic banks, such as product, location, services, etc. So, if the Islamic banks are going to increase the growth of deposit funds, the Islamic banks must increase several things, such as the service quality, product quality, product innovation, etc. Sharia reason is only one reason from the customer why 
they choose the Islamic banks (Usman, 2015; Sari et al., 2015; Soma et al, 2017), but not the dominant factors. So, the spin-off decision that imposed by the regulator because of the Sharia reason is not indeed correct. The Sharia compliance is not because of the Islamic business unit form, but, comes from the Islamic bank's operations. The Islamic bank also had to increase the service quality; it will increase the loyalty of the customers (Suryani and Hendryadi, 2015; Hidayat et al., 2015).

Tübke (2004) said several factors affect the spin-off process. First, the business activity factor, such as the company size and the business orientation of the subsidiaries. Second, the organization and management factor. Third, the relationships and support element. There are three patterns of relationships, namely the market-relatedness, the product-relatedness, and the technology-relatedness. Fourth, transfer consideration or transfer such transfer of experience from the parent company to its subsidiaries. Fifth, the motivation factor. Sixth, the business environment factor.

Actually, besides the spin-off policy, other strategies can be done to accelerate the growth of Islamic banking industry, i.e., merger. Miftah and Wibowo (2017) said that the merger would optimize the acceleration of Indonesian Islamic banking industry. Besides that, five alternatives are feasible considering when doing the merger, i.e., internal aspect and external aspect.

\section{Conclusion}

From the research that has done by using a fixed effects model showed that the policy of separation has a positive influence on deposit funds in Islamic banks separation results. Based on the estimates indicate that the fixed effects model (fixed effect) gives the highest determination coefficient compared to the OLS model and a random-effects model (random effect). Internal factor that influence is the level of operational efficiency (measured by BOPO), while the external factors that affect the interest rate are of conventional banks and economic growth.

These findings have several implications for the growth of Islamic banks in Indonesia. First, policy spin-offs that have been carried out by four banks proved to increase deposit funds. Second, Islamic business units should be given incentives to immediately want to take a spin-off policy before 15 years after the law is applied. Third, the internal factors and external factors also contribute an element that can improve deposit funds in Islamic banks.

The policy implications of this research are: first, the spin-off decision is one of the business strategies from Islamic banks and not a goal of Islamic banking industry. Second, the Islamic banks should still increase the bank's product quality. Third, the Islamic banks should always make the innovation of the product. Fourth, the parent's banks should support the operation of the subsidiaries.

The limitation of this research is the data that only focus on the spin-off's banks. The future research should also add the non-spin-offs' banks, to enrich the result and policy implication for the policymakers. By entering the non-spin-offs' banks, the effect of spin-off policy on deposit funds will be seen clearly.

\section{References}

Al Arif, MNR, 2014, 'The Impact of Spin-off Policy on Islamic Banking Industry in Indonesia', Economic Journal of Emerging Market. Vol. 6, no. 1, pp. 50-55.

Al Arif, MNR, 2015, Keterkaitan Kebijakan Pemisahan Terhadap Tingkat Efisiensi pada Industri Perbankan Syariah di Indonesia (The Relationship of Spin-off Policy To Efficiency Ratio in The Indonesian Islamic Banking Industry), Jurnal Keuangan dan Perbankan. Vol. 19, no. 2, pp. 295-304.

Al Arif, MNR, 2015, The Effect of Spin-off Policy on Financing Growth in Indonesian Islamic Banking Industry, Journal Al-Ulum, Vol. 15, no. 1, pp. 173-184.

Al Arif, M.N.R, 2015, Impact of Spin-off Policy on The Asset Growth on Indonesian Islamic Banking Industry, Journal of Islamic Economics, Banking, and Finance, Vol. 11, no. 4, pp. 41-52

Al Arif, M.N.R., Nachrowi, ND, Nasution, ME, \& Mahmud, TMZ, 2017, The Islamic Banking Spin-Off: Lessons from Indonesian Islamic Banking Experience, JKAU: Islamic Economics, Vol. 30 no. 2, pp. 117-133.

Andriyanti, A \& Wasilah, 2010, Faktor-faktor yang Mempengaruhi Deposito Mudharabah di Bank Muamalat Indonesia (The Factors that Influence the Mudharabah Deposit Funds at Bank of Muamalat Indonesia), Paper at Simposium Nasional Akuntansi XIII, Universitas Jenderal Soedirman Purwokerto.

Cristo, DA \& Falk, RW, 2006, Spinoffs and Carveouts: Some Factors Leading to Successful Divestiture, Competition Forum, Vol. 4, no. 2, pp. 331-347 
Elfring, T \& Foss, NJ, 1997, Corporate Renewal Through Internal Venturing and Spin-offs: Perspectives from Organizational Economics, Working Paper 97-7, Department of Industrial Economics and Strategy Copenhagen Business School.

Endri, 2011, The Evalution of Technical Efficiency in Indonesian Banks: Using the Two-Stage DEA, Paper at Forum Riset Perbankan Syariah IV. Jakarta: The Indonesian Association of Islamic Economist and Bank of Indonesia.

Hamid, A, 2015, The Impact of Spin-off Policy to The Profitability on Indonesian Islamic Banking Industry, Al-Iqtishad: Jurnal Ilmu Ekonomi Syariah (Journal of Islamic Economics), Vol. 7, no. 1, pp. 117-126.

Haribowo, I, 2017, The Indonesian Islamic Bank's Spin-Off: A Study in Regional Development Banks, Al-Iqtishad: Jurnal Ilmu Ekonomi Syariah (Journal of Islamic Economics), Vol. 9, no. 1, pp. 53-68.

Hidayat, R, Sabarudin, A \& Machmud, 2015, Effects of Service Quality, Customer Trust and Customer Religious Commitment on Customer Satisfaction and Loyalty of Islamic Banks in East Java, Al-Iqtishad: Jurnal Ilmu Ekonomi Syariah (Journal of Islamic Economics), Vol. 7, no. 2, pp. 151-164

Kasri, RA, 2010, The Determinant of Islamic Banking Growth in Indonesia, Journal of Islamic Economics, Banking and Finance, Vol. 6, no. 2, pp. $41-64$.

Kiswono, B. ,2012, Islamic Business Unit's Spin-off: Barrier and Strategy. Working paper, Jakarta: Bank Indonesia.

Miftah, K \& Wibowo, H, 2017, Merger and Industrial Acceleration: Study at Indonesian Islamic Banking Industry, Signifikan: Jurnal Ilmu Ekonomi, Vol. 6, no. 1, pp. 29-48.

Nasuha, A, 2012, Dampak Kebijakan Spin-Off Terhadap Kinerja Bank Syariah (The Impact of Spin-off Policy on Islamic Bank Performance), Al-Iqtishad: Jurnal Ilmu Ekonomi Syariah (Journal of Islamic Economics), Vol. 4, no. 2, pp. 241-258.

Novarini, 2009, Efisiensi Unit Usaha Syariah Menggunakan SFA: Derivasi Fungsi Profit dan BOPO (The Efficiency of Islamic Business Unit using SFA: Profit Function and BOPO Derivation), (Unpublished Thesis), Depok [ID]: University of Indonesia.

Pramuka, BA, 2011, Assesing Profit Efficiency of Islamic Banks in Indonesia: An Intermediation Approach, Journal of Economics, Business and Accountancy Ventura, Vol. 14, no. 1, pp. 79-88

Ramdani, A, 2015, Pengaruh Kebijakan Pemisahan Terhadap Laba Pada Bank BNI Syariah (The Effect of Spin-off Policy on Profit at Bank of BNI Sharia), Etikonomi, Vol. 14, no. 1, pp. 17-34.

Sari, IM, Wibowo, H, \& Suprapto, E, 2015, Factors that Influenced People to Become Islamic Bank Customer: A Study on Kanca Villagers, Al-Iqtishad: Jurnal Ilmu Ekonomi Syariah (Journal of Islamic Economics), Vol. 7, no. 1, pp. 73-86

Siswantoro, D, 2014, Analysis of Islamic Banks Performance and Strategy After Spinoff as Islamic Full-Pledge Scheme in Indonesia, International Conference on Accounting Studies, 18 - 19 August 2014, pp. 41-48

Soma, AM, Primiana, I, Wiryono, SK, \& Febrian, E, 2017, Religiosity and Islamic Banking Product Decision: Survey on Employees of PT Telekomunikasi Indonesia, Etikonomi, Vol. 6, no. 1, pp. 25-42.

Suryani \& Hendryadi, 2015, A Developing Model of Relationship Among Service Quality, Customer Satisfaction, Loyalty and Word of Mouth, Al-Iqtishad: Jurnal Ilmu Ekonomi Syariah (Journal of Islamic Economics), Vol. 7, no. 1, pp. $45-58$

Usman, H, 2015, The Role of Religious Norms on Selecting The Islamic Bank, Al-Iqtishad: Jurnal Ilmu Ekonomi Syariah (Journal of Islamic Economics), Vol. 7, no. 1, pp. 31-44 